\title{
Evaluation of microbial quality of the surface water of Hatirjheel in Dhaka City
}

\author{
Md. Badsha Miah, Ahmad Kamruzzaman Majumder* and Gulshan Ara Latifa \\ Department of Environmental Science, Stamford University Bangladesh, 744, Satmasjid Road, Dhaka 1209, \\ Bangladesh
}

Received 21 June 2016/Accepted 29 July 2016

\begin{abstract}
Microbiological health risks due to environmental pollution are major concerning issue in all over the world. In Bangladesh, almost all the major water bodies (lake/khal) particularly in the urban or semiurban area have been suffering severely pollutions. Therefore if we manage to safe our surface water in and around the city, we can reduce the demand of ground water for the city dwellers by the proper use of these lakes and ponds. This study was conducted to evaluate the microbial condition of Hatirjheel water located in Dhaka City. The microbial analysis was performed to trace the presence of bacterial and other pathogens. In 5 samples, total viable bacteria and fungi were found up to $2.0 \times 10^{6}$ $\mathrm{cfu} / \mathrm{ml}$ and $3.4 \times 10^{2} \mathrm{cfu} / \mathrm{ml}$, respectively. Specific pathogens such as Klebsiella $\mathrm{spp} .\left(3.0 \times 10^{2} \mathrm{cfu} / \mathrm{ml}\right)$, Salmonella spp. $\left(2.0 \times 10^{2} \mathrm{cfu} / \mathrm{ml}\right)$, Pseudomonas spp. $\left(8.3 \times 10^{2} \mathrm{cfu} / \mathrm{ml}\right)$ and Vibrio $\mathrm{spp} .\left(6.0 \times 10^{2} \mathrm{cfu} / \mathrm{ml}\right.$.) were also isolated. The findings of the study revealed that the water of Hatirjheel might not safe for human health and also indicated that this water may vulnerable for diarrhea, dysentery, typhoid fever, shigellosis, salmonellosis, parasitic worm infection, hemolytic uremina syndrome etc. water-borne diseases. The poor water quality suggesting contamination of the lake water by domestic and industrial wastes and other anthropogenic activities. So it is important to control the pollution for proper use of this water in various household purposes.
\end{abstract}

Key words: Water quality; Microorganisms; Pollution; Lake, Health impact

Water is the most important components amongst the natural resources and fundamental for the continued existence of all living organisms. The environment, economic growth and development of Bangladesh are all highly influenced by water- its regional and seasonal availability and the quality of surface and groundwater. The inexorable rise in demand for water to grow food, supply industries and sustain urban and rural populations has led to a growing scarcity of freshwater in many parts of the world. The world is experiencing a steady decline in water quality and its availability. About 75 percent of the world's rural and 20 percent of its urban population has no ready water access to uncontaminated water (1). For many regions, water supplies are contaminated with toxic chemicals and pathogenic microorganisms. In terms of quality, the surface water of the country is unprotected from untreated industrial effluents and municipal wastewater (2-4).

Lakes and ponds are a vital part of a modern healthy city. Over the past few decades, as Dhaka started to grow into a mega city, we began to realize how important it is to have parks, natural wetland, lakes, and

*Corresponding Author: Mailing address. Dr. Ahmad Kamruzzaman Majumder, Department of Environmental Science, Stamford University Bangladesh, 744 Satmasjid Road, Dhaka 1209, Bangladesh; E-mail: kamrul_subd@yahoo.com open spaces. The surface water area of Dhaka city is about $10-15 \%$ of the total land area. Hatirjheel, Gulshan Lake, Banani Lake, Ramna Lake and Dhanmondi Lake are the popular relaxation spot in the city, is being polluted by slums and sewages, the business firms and industries operating in the area, locals and environmentalists alleged. But unfortunately, the groundwater level in many areas of Dhaka city is drastically receding from about $0.3 \mathrm{~m}$ per year at Banani to about $1 \mathrm{~m}$ per year at Motijheel (5). Therefore if we manage to safe our surface water in and around the city, we can reduce the demand of ground water for the city dwellers by the proper use or these lakes and ponds.

Haitrjheel is a prominent depression within Dhaka metropolitan area. The Lake is about 302 acres of Tejgaon, Moghmazar, Rampura region and has been playing a vital role in maintaining the only drainage system of those areas. The open stage for cultural programs and a number of beautiful bridges and roads attract a large number of visitors every day. The situation is getting worse due to the lack of adequate entertainment spots in the capital. Tile Lake and its adjacent area become crowded during the weekends. Residents of the area also alleged that liquid wastes from sewages are dumped into the lake. Garbage and human faeces have made the water of the lake greenish. A research work showed that $\mathrm{pH}$ varied from 6.7 to 7.1 , Color varied from 25 to $50 \mathrm{pt}-\mathrm{Co}$ units, turbidity varied from 0 to $13 \mathrm{NTU}$, 
from 0 to $13 \mathrm{NTU}$, carbon dioxide $\left(\mathrm{CO}_{2}\right)$ varied from 35 to $60 \mathrm{mg} / \mathrm{l}$, alkalinity varied from 90 to $345 \mathrm{mg} / \mathrm{l}$, hardness varied from 150 to $300 \mathrm{mg} / \mathrm{l}$, chloride varied from 0.5 to $1.0 \mathrm{mg} / \mathrm{l}$, BOD varied from 0.0 to $10 \mathrm{mg} / \mathrm{l}$, COD varied from 28 to $60 \mathrm{mg} / \mathrm{l}$ at Hatirjheel water (6).

The quality of water is of vital concern for mankind, since it is directly linked with human well-being. At present, the menace of water borne diseases and epidemics still loom large on the horizons of developing countries (7). The increasing urbanization and industrialization of Bangladesh have negative implications for surface water quality. The pollution from industrial and urban waste effluents and from agrochemicals in some water bodies and rivers has reached alarming levels (8-10). In Bangladesh, about $80 \%$ of all diseases are associated with water-borne microbes. About 300,000 children under five, die of diarrheal diseases every year, out of which one-third of the death occurs in the city slums and squatter settlements (11). The physicochemical features and bacterial flora of Dhanmondi Lake were investigated earlier (12-14).

Microbial safety of recreational water is one of the major human public health issues in developing countries. Water contamination occurs through contamination of streams, lakes, underground water, bays, or oceans by substances harmful to living things. If severe, water pollution can kill large numbers of fish, birds and other animals in some cases killing all members of a species in an affected area. Pollutions make streams, lakes, and coastal waters unpleasant to look at, to smell, and to swim in. People who ingest polluted water can become ill, and with prolonged exposure, may develop cancers or bear children with birth defect.

Aquatic microorganisms and their activities are of great importance in many ways. These organisms occupy a key position in the food chain by providing rich nourishment for the next higher level of aquatic life and may affect health of humans and other animals (15-18). Water quality maintenance means that natural waters should not be overloaded with organic or inorganic nutrients or with toxic, noxious, or esthetically unacceptable substances. They should not become vehicles of disease transmission from fecal contamination nor should their oxygenation, temperature, salinity, turbidity, or $\mathrm{pH}$ be altered significantly (19). Since water pollution is the common scenario, its effect on the environment must be studied thoroughly and regularly. Therefore, the present study was undertaken to evaluate the microbial quality of water, of Hatirjheel.

\section{MATERIALS AND METHODS}

Study Area and collection of Sample. The study area chosen for the current investigation was Hatirjheel of Dhaka city and a total of 5 surface water samples were collected aseptically in pre-sterilized screw caped bottles. Bottles were marked properly and transported to the laboratory as early as possible for microbiological analysis. Serial dilution of water samples were made in sterile normal saline up to $10^{-5}(15,16)$.

Isolation and enumeration of total viable bacteria and fungi. $0.1 \mathrm{ml}$ of each sample from $10^{-3}$ and $10^{-5}$ dilutions was dispensed in to the Petri plates with sterile nutrient agar medium. Plates were incubated at $37{ }^{\circ} \mathrm{C}$ for 24 hours. Similarly, sample from dilution $10^{-2}$ was inoculated on to Sabouraud Dextrose Agar (SDA) medium and the plates were incubated at $25^{\circ} \mathrm{C}$ for 48 hours.

Isolation and enumeration of pathaogenic bacteria. For the isolation of E. coli, Klebsiella spp. and Pseudomonas spp. an aliquot of $0.1 \mathrm{ml}$ of each sample from dilution $10^{-2}$ was inoculated on to MacConkey agar and cetrimide agar medium, respectively. The plates were allowed to incubate for 24 hours at $37{ }^{\circ} \mathrm{C}$. TCBS (Thiosulfate-citrate-bile salts-sucrose) agar and Salmonella-Shigella agar medium were used for the isolation of Vibrio spp., Salmonella spp. and Shigella spp., respectively $(15,16)$.

\section{RESULTS AND DISCUSSION}

Microbial quality of water is usually expressed in terms of the concentration and frequency of occurrence of particular species of bacteria. Polluted water may contain pathogenic bacteria, viruses, protozoa or helminthes eggs. Some of the bacteria that indicate the presence of other kinds of pathogens are called indicator bacteria. They are usually present in the colon and excreted in large number by warm blooded animals (16-19).

The outcome of microbial analysis performed on samples collected from different locations of Hatirjheel of Dhaka, Bangladesh appears in Table 1. All of the samples contained huge array of bacterial load. Maximum total viable bacterial load $\left(2.0 \times 10^{6} \mathrm{cfu} / \mathrm{ml}\right)$ found in sample 2 and minimum $\left(2.8 \times 10^{5} \mathrm{cfu} / \mathrm{ml}\right)$ found in sample 5. Total fungi count on SDA agar ranged between 0 to $3.4 \times 10^{2}$ $\mathrm{cfu} / \mathrm{ml}$. Two samples were devoid of fungi. E. coli was absent from all samples (Table 1). The lowest load of Klebsiella spp. $\left(1.6 \times 10^{2} \mathrm{cfu} / \mathrm{ml}\right)$ was recorded in the sample 5 while the highest number $\left(3.0 \times 10^{2} \mathrm{cfu} / \mathrm{ml}\right)$ was in the sample 3. The highest load of Pseudomonas spp. on Cetrimide agar medium was $8.3 \times 10^{2} \mathrm{cfu} / \mathrm{ml}$. No Shigella spp. was found in all samples and Salmonella spp. count ranged between 0 to $2.0 \times 10^{2} \mathrm{cfu} / \mathrm{ml}$. The Vibrio spp. count on TCBS agar ranged between 0 to $6.0 \times 10^{2} \mathrm{cfu} / \mathrm{ml}$ (Table 1).

According to WHO Standards, E. coli or thermotolerant coliform bacteria must not be detectable in any $100 \mathrm{ml}$ of sample (20). This study clearly revealed that the surface water was loaded with bacterial species. Saha et al. (13) found Bacillus spp., Salmonella spp., Escherichia spp., Enterobacter spp., Serratia spp., Pseudomonas spp. and other pathogens in Dhanmondi Lake water in their study. It indicates that many species were potentially pathogenic and are able to cause a spectrum of infections in susceptible populations. Water intended for drinking and household purposes must not contain any water borne pathogens $(15,16)$. The pathogenic groups includes bacteria, viruses and protozoa, which causes diseases that vary in severity from mild gastroenteritis to sever fataldiarrhoea, dysentery, hepatitis, typhoid fever etc,. Apart from routine microbiological examination for evidence of 
TABLE 1. Microbial count (cfu/ml) of surface water samples of Hatirjheel

\begin{tabular}{ccccccc}
\hline Sample & $\begin{array}{c}\text { TVB } \\
(\mathbf{c f u} / \mathbf{m l})\end{array}$ & $\begin{array}{c}\text { Total } \\
\text { Fungi } \\
(\mathbf{c f u} / \mathbf{m l})\end{array}$ & $\begin{array}{c}\text { Klebsiella spp. } \\
(\mathbf{c f u} / \mathbf{m l})\end{array}$ & $\begin{array}{c}\text { Pseudomonas } \\
\text { spp. }(\mathbf{c f u} / \mathbf{m l})\end{array}$ & $\begin{array}{c}\text { Salmonella } \\
\text { spp. (cfu/ml) }\end{array}$ & $\begin{array}{c}\text { Vibrio spp. } \\
(\mathbf{c f u} / \mathbf{m l})\end{array}$ \\
\hline S-1 & $4.6 \times 10^{5}$ & 0 & 0 & $5.8 \times 10^{2}$ & 0 & 0 \\
S-2 & $2.0 \times 10^{6}$ & $3.4 \times 10^{2}$ & $2.0 \times 10^{2}$ & 0 & $2.0 \times 10^{2}$ & 0 \\
S-3 & $6.5 \times 10^{5}$ & $3.0 \times 10^{2}$ & $3.0 \times 10^{2}$ & $1.0 \times 10^{2}$ & 0 & 0 \\
S-4 & $3.4 \times 10^{5}$ & 0 & $2.6 \times 10^{2}$ & 0 & 0 & $6.0 \times 10^{2}$ \\
S-5 & $2.8 \times 10^{5}$ & $1.6 \times 10^{2}$ & $1.6 \times 10^{2}$ & $8.3 \times 10^{2}$ & 0 & 0 \\
\hline
\end{tabular}

$\mathrm{TVB}=$ Total viable bacteria

E. coli and Shigella spp. were absent in all samples

fecal contamination, other pathogenic microorganisms must be tested. Absence of indicator microorganism in water body does not actually indicate that absence of infection potential. The detection of pathogens i.e., Salmonella spp., Klebsiella spp. and other pathogens from natural waters is still to be established due to their low concentration $(21,22)$.

Surface waters are vital and vulnerable fresh water systems that are critical for the sustenance of all life. Social, economic and political development has been largely related to the availability and distribution of freshwaters contained in surface water systems. Surface water systems can be considered as arteries of the land supplying life giving water to an abundance of organisms whilst at the same time supporting modern civilizations $(13,14)$. Since it is directly linked to the human welfare, water quality is of major concern for mankind (7).

\section{CONCLUSION}

Microbial study revealed that the microbial quality of different location of Hatirjheel was diverse. The microbial analysis was performed to trace the presence of organisms and pathogens such as E.coli, Salmonella spp., Shigella spp., Klebsiella spp. and Vibrio spp. Presence of pathogenic bacteria in water indicates that water is not safe for household purposes and might vulnerable for causation and spread of different waterborne diseases. The findings of the current study suggest that the purpose of the Hatirjheel project will not be fully gained until the water pollution from different sources is controlled. So, it is need to take necessary steps to stop the pollution of water and increase the quality of water such as setup effluent treatment plants (ETP) at the sewage and waste water discharging points. Regular monitoring is needed to get the desired water quality, continuing the sound water quality and to restore and maintain the physical, chemical and biological integrity of water bodies to achieve the required water quality, which ensure protection and propagation of fish, wildlife, plants and also recreation in and on water.

\section{ACKNOWLEDGEMENT}

Authors thank Dr. Rashed Noor, Chairman, Department of Microbiology, Stamford University Bangladesh for his cooperation in conducting the research and write up of the manuscript. Authors also thank the Microbiology Laboratory of Stamford University Bangladesh for providing facilities to carry out the experiment.

\section{REFERENCES}

1. UNEP. 2002. Water Supply and Sanitation Coverage in UNEP Regional Seas. Hague, Netherlands.

2. GoB (Government of Bangladesh). 2001. State of environment Bangladesh 2001. Available at: http://www.moef.gov.bd/html/state_of_env.html Accessed 27 February, 2016.

3. Higgins IJ, Burns RG. 1975. The chemistry and microbiology of pollution. Academic Press, London.

4. Kelsey H, Porter DE, Scott G, Neet M, White D. 2004. Using geographic information systems and regression analysis to evaluate relationships between land use and fecal coliform bacterial pollution. J. Exp. Mar. Biol. Ecol. 298: 197-209.

5. Nishat M, Reazuddin, Amin R, Khan AR. 2000. The 1998 flood: Impact on the environment of Dhaka City. Department of Environment and IUCN, Bangladesh, Dhaka.

6. Alam MS. 2014. Assessment of water quality of Hatirjheel Lake in Dhaka city. International Journal of Technology Enhancements and Emerging Engineering Research. 2 (6): 97-100.

7. Jain S. 2012. Assessment of water quality at the three stations of Chambal River. International Journal of Environmental Sciences. 3 (2): 881-884.

8. Ahmed AU, Reazuddin, 2000. Industrial pollution of water systems in Bangladesh, University Press Limited, Dhaka.

9. Mason C. 2002. Biology of freshwater pollution. Pearson Education, Harlow, UK.

10. Sarwar MI, Majumder AK, Islam MN. 2010. Water quality parameters: A case study of Karnafully River Chittagong, Bangladesh. Bangladesh Journal of Scientific and Industrial Research. 45 (2): 177-181.

11. GOB-UNICEF. 1991. Rural water supply and sanitation program. 19921999, Dhaka, Bangladesh.

12. Khondker M, Parveen L. 1992. Study on the physicochemical limnology of a shallow, hypertrophic artificial lake. Bangladesh J. Sci. Res. 10 (1): 9-16. 
13. Saha ML, Khan MR, Rahman R, Hoque S. 2002. Pollution level and bacterial flora of the re-excavated Dhanmondi Lake, Dhaka, Bangladesh. Bangladesh J. Bot. 31 (1): 9-13.

14. Islam R, Sikder MT, Majumder AK, Haque SA. 2010. Surface water quality of the hydrological environment of Dhanmondi Lake, Journal of Environmental Science \& Natural Resources. 3 (1): 57-60.

15. Munshi SK, Rahman MM, Noor R. 2012. Detection of virulence potential of diarrheagenic Escherichia coli isolated from surface water of rivers surrounding Dhaka city. J. Bang. Acad. Sci. 36 (2): 109-121.

16. Acharjee M, Jahan F, Rahman F, Noor R. 2013. Bacterial prolifiration in municipal water supplied in Mirpur locality of Dhaka city, Bangladesh. CLEAN- Soil Air Water. 41: 1-8.

17. Pelczar MJ, Chan ECS, Krieg NR. 1988. Microbiology. McGraw-Hill, New York
18. Okonko IO, Ogunnusi TA, Adejoye OD, Shittu OB. 2008. Microbiological and physicochemical analysis of different water samples use for domestic purposes in Abeokuta, Ogun State and Ojota, Lagos State, Nigeria. African Journal of Biotechnology. 7 (5): 617-621.

19. SEAWA. 2009. Geography of the South Saskatchewan River Basin. SEAWA watershed report 2009

20. WHO (World Health Organization). 1993. Guidelines for drinking-water quality, $2^{\text {nd }}$ ed. Geneva, Switzerland.

21. Atlas RM, Bartha R. 1998. Microbial ecology, $4^{\text {th }}$ ed. Addison Wesley Longman, Inc., California.

22. APHA. 1998. Standard methods for the examination of water and wastewater American Public Health Association, Washington, DC. 